\section{SUSTAINABLE DEVELOPMENT AND STAKEHOLDER RELATIONS MANAGEMENT: Exploring Sustainability Reporting in the Hospitality Industry from a SD-SRM approach}

\section{ABSTRACT:}

This paper explores the sustainability reporting of 170 hospitality companies from a SD-SRM approach. The purpose of the study is to ascertain the information that companies disclose in accordance with the sustainable development (SD) and the stakeholder relations management (SRM) theories and to identify the areas for improvement in the management and reporting practices of sustainability in the hospitality industry. The authors use the content analysis method to identify and describe the sustainability reporting of hotel chains and independently managed hotels in Spain. The findings show that the sustainability information reported by hospitality companies currently meets the basic principles of a SD-SRM approach. Nonetheless, the authors also identify areas for improvement such as the orientation of the reporting to suppliers or the more equilibrated distribution of information among all corporate stakeholders. Based on these findings, the authors consider that the integration of information following the SD-SRM approach described in this paper could facilitate a better compliance of hospitality companies with the principles of the SD and SRM theories.

\section{KEYWORDS:}

Sustainability; sustainable development; stakeholders; hotels; reporting

\section{CLASSIFICATION:}

Research paper 
Tourism is one of the main service industries worldwide. Roughly speaking, it generates $\$ 2$ trillion and provides employment for the $15 \%$ of the world's economically active population annually (Martínez et al., 2013). Thus, if used responsibly tourism can be a force for positive growth and economic success (Dodds and Kuehnel, 2010). It has the capacity to create employment, generate opportunities in many areas where other economic activities may not exist, bring earnings and foreign exchange, provide civil infrastructure, help preserve the local environment and provide wellbeing to the local community. However, if used irresponsibly it can also be a source for leakage, low fares and seasonal employment, instability and low job status, environmental degradation, displacement of local people, inflation and the dilution of culture (Agarwal, 2002). In this context, sustainability has gained momentum in the tourism industry, where companies must play a role in the exercise of good governance practices (Martínez et al., 2013).

Sustainability in the tourism industry has been defined from two theoretical approaches. Firstly, some scholars consider that the sustainable development theory (van Marrewijk, 2003; Panwar et al., 2006) provides the most suitable approach to the study of sustainability in tourism industries (Martínez et al., 2013). Under the light of this perspective, sustainability is reinforced as a multidimensional construct that equally emphasizes the economic, social and environmental duties of companies (Panwar et al., 2006). These three dimensions refer to the triple-bottom line of the company. The economic dimension is based on ensuring viable economic activities in the long term so that all stakeholders receive appropriately distributed socioeconomic benefits (Dyllick and Hockerts, 2002). The social dimension refers to a respect for the cultural authenticity of host communities, the preservation of their architectural and living cultural assets and traditional values, and a contribution to intercultural understanding and tolerance (Dyllick and Hockerts, 2002). The environmental dimension refers to the optimal use of environmental resources, which is an essential element of tourism development, protecting essential ecological processes and helping to conserve natural resources and biodiversity (Dyllick and Hockerts, 2002). Secondly, scholars aligning with the stakeholder relations management theory (stakeholder theory) (Freeman, 1984) consider that emphasizing pro-social (economic, social or environmental) deeds will do little to enhance corporate reputation for sustainability if the company is simultaneously perceived to be harming other individuals or stakeholders, or even deceiving the public about such matters (Steurer et al., 2005). Thus, the stakeholder theory defends that sustainability should be evaluated on the basis of those stakeholders who benefit the most from pro-social initiatives because they are the target audiences of each corporate behaviour.

The ideas of sustainable development and stakeholder theories have been combined in numerous definitions of sustainability in the business and academic spheres. For example, the European Commission (2001) defines sustainability as a concept designed to help companies integrate social and ecological concerns into their corporate activities and relationships with stakeholders. Along this line, the World Bank (2004) defines it as the commitment of businesses to contribute to sustainable economic development, working with employees, their families, the local community, and society at large to improve the quality of life in ways that are good for business and good for development. From an academic perspective, Dahlsrud (2008) provides a review of 37 definitions of corporate social responsibility and sustainability that support the relevance of sustainable development and stakeholder approaches. For example, van Marrewijk (2003) defines sustainability as all company activities demonstrating the inclusion of social and environmental concerns in business operations, and in interactions with stakeholders, also according to the ambition levels of corporate sustainability. Similarly, Dyllick and Hockerts (2002) considers that sustainability is about meeting the needs of a 
company's direct and indirect stakeholders (such as shareholders, employees, customers, pressure groups, communities, etc), without compromising its ability to meet the needs of future stakeholders as well. Towards this goal, companies have to maintain and grow their economic, social and environmental capital base while actively contributing to sustainability in the political domain (Dyllick and Hockerts, 2002). Hopkins (2003) also suggests that sustainability is concerned with treating the stakeholders of the company ethically or in a responsible manner. Ethicality or responsibility means treating stakeholders in a manner deemed acceptable in civilized societies. According to this definition, this scholar considers that the wider aim of sustainability is to create higher and higher standards of living, while preserving the profitability of the company, for people both within and outside the company (Hopkins, 2003). All in all, Dahlsrud (2008) gets to the conclusion that the existing definitions of sustainability are to a large degree congruent and so there should be no confusion in the understanding of this concept (Dahlsrud, 2008).

Nonetheless and in spite of the general consensus that sustainable development and stakeholders are closely interconnected, when exploring the links of both approaches from an academic perspective, scholars have tended to limit their contributions to the proposition of these comprehensive definitions of sustainability (Jones et al., 2005; Steurer et al., 2005; Konrad et al., 2006; Holcomb et al., 2007; Dodds and Kuehnel, 2010). However, they have not gone any deeper to clarify how the integration of sustainable development and stakeholder relations management can be (or is being) implemented in companies. For example, Jones et al. (2005) subscribe the comprehensive definitions provided by the European Commission (2001) and the World Bank (2004). However, when describing the online sustainability reporting of UK retailers, these authors base on four principal headings that merely align with the stakeholder theory. These headings are named 'environment', 'marketplace', 'workplace' and 'community' (Jones et al., 2005). These sustainability categories include sustainable development issues such as environmental concerns (e.g., energy consumption and emissions, raw material usage, water consumption, etc) or social concerns (e.g., charitable contributions to local and national organisations, etc) but nowhere in their paper the scholars describe how stakeholder management can normatively or instrumentally (Steurer et al., 2005) assist companies in the promotion of sustainable development. Similarly, Holcomb et al. (2007) implement a content analysis of online information to describe the sustainability reporting of international hospitality companies. These scholars present a framework of five sustainability dimensions named 'community', 'environment', 'marketplace', 'vision and values' and 'workforce' (Holcomb et al., 2007). Following the proposal of Jones et al. (2005), these dimensions also encompass sustainable development concerns such as 'charitable donations', 'community welfare', 'corporate giving', 'cultural heritage' or 'energy management', among others. Nonetheless, these scholars do not classify the sustainable development issues into the dimensions of the triple-bottom line and the sustainability structure they propose lead to the same question that previous studies have failed to answer: how far sustainable development can be achieved through stakeholder management and how both approaches relate to each other?. Thus, the lack of an integrative approach to the study of sustainability management in companies has always complicated understanding and gauging the degree of sustainability compliance in the business world (Steurer et al., 2005) and new research is needed along this line.

Based on these ideas, the aim of the authors in this paper is to present a theoretical framework that integrates the two major approaches that have been used in the academic literature to study sustainability in companies: sustainable development and stakeholder relations management. This new framework, named the SD-SRM approach, allows scholars and practitioners to more easily evaluate the achievement of the various objectives linked to sustainability in the business arena in terms of sustainable development and stakeholder 
management goals. The theoretical framework for the study of sustainability is also applied to the empirical analysis of the reporting practices of two samples of hospitality companies. The empirical study allows the authors to identify areas of significant improvement in the performance and communication of sustainability in the hospitality industry.

The remainder of the paper is structured as follows. First, the authors review the sustainable development and stakeholder theories to propose the integrative framework suggested for the study of sustainability in the hospitality industry. Furthermore, the authors describe the method they apply to study the reporting practices of hospitality companies based on this theoretical framework. The authors discuss the results of the paper. Finally, they present their conclusions, managerial implications, limitations and future lines of research derived from the study.

\section{SUSTAINABLE DEVELOPMENT AND STAKEHOLDERS: THE SD-SRM APPROACH APPLIED TO THE HOSPITALITY INDUSTRY}

\subsection{Sustainable development}

In mid 1980s sustainable development (SD) became a prominent concept known both in academic and professional circles. The UN Report "Our Common Future" defines SD as the development that meets the needs of current generations without compromising the ability of future generations to meet their needs and aspirations. It first referred to issues strictly related to the environment but in the course of the 1990s the scope of SD was broadened and deepened to also include social and economic issues (Dyllick and Hockerts, 2002). Thus, today SD is a well-known societal guiding model that asks for the integration of economic, social and environmental issues in all societal spheres and levels in the short- and long-term (Steurer et al., 2005). Nonetheless, some scholars, such as Castro (2004), have criticized different implications of this theory for being too vague, for not defining what needs are, or for not saying what are the mechanisms to achieve a sustainable society. Thus, along with the threedimensional idea, other two principles guide the theoretical discourse of the SD theory: (1) its building on normative foundations (what companies 'should' do) and (2) the participation of stakeholders in the discussion of sustainability issues (Steurer et al., 2005).

The theoretical approach of SD has been widely applied in the field of tourism (Kakabadse et al., 2005; Henderson, 2007; Martínez et al., 2013). In a market still struggling to regain its balance after the worldwide crisis, the society is increasingly sensitive to economic, social and environmental problems. This fact leads tourists and local communities to demand the protection of the cultural and environmental heritage of tourism destinations (Bigné et al., 2000). In this sense, many international initiatives show the growing importance of SD in the tourism industry. For instance, the Agenda 21 was created by the World Travel and Tourism Council (WTTC), the World Tourism Organization (WTO) and the Earth Council as a set of international guidelines relative to SD in tourism companies. In Europe, a similar proposal is the Initiative for Improving Sustainability in the Hospitality Sector, which was drafted by the European Federation of Food and Agriculture and Tourism Trade Unions and Hotels, Restaurants and Cafés in Europe. This initiative includes compliance parameters concerning equal opportunity, non-discrimination, working conditions, fair pay, vocational training and life-long learning, health and safety, and the relationship between employers and employees at all levels. Other initiatives, such as that of the Green Hotels Association, focus on programs that are designed to save water, energy and solid wastes. Finally, the Green Hotelier, a 
publication of the International Tourism Partnership, is a magazine whose readership cares about environmentally and socially responsible hotel behaviour as focused upon positive sustainable travel and tourism development.

\subsection{Stakeholder relations management}

While the SD theory describes the relationship between companies and the larger society, in rather general terms, the stakeholder relations management (SRM) theory is about actually managing company-society relations in a strategic way (Clarkson, 1995; Steurer et al., 2005). In this regard, stakeholders seem to play an increasingly important role for the achievement of normative concepts such as SD (Konrad et al., 2006). Stakeholders influence companies because they supply them with critical resources. Thus, if companies fail to identity and understand the interests of their stakeholders, their performance may be negatively affected (Wheeler et al., 2002). As sustainability is gaining momentum worldwide, companies begin to realize that their stakeholders are demanding behaviours and accountability that go beyond shareholders' interests (Williams and Adams, 2013). Subsequently, they are increasingly being regulated and corporate strategic initiatives focusing on improving SRM are on the rise (Dodds and Kuehnel, 2010).

The SRM theory (Freeman, 1984) defines stakeholders as those groups or individuals who can affect or are affected by the achievement of the company's objectives or those actors with a direct or indirect interest in the company. This perspective describes sustainability as the obligations companies have towards these groups (Maignan and Ferrell, 2004) and thus it suggests a dimensioning of sustainability according to the main target groups of the company. In this line, Clarkson (1995) considers that companies and practitioners manage relationships with stakeholders instead of society as a general concept so we better address stakeholders' concerns instead of social ones. According to this proposal, sustainability practices should preferably be classified as a function of those stakeholders who are most benefited by them. Applying this reasoning, scholars have identified several sustainability dimensions (e.g., customers, employees, shareholders, the environment, providers).

The SRM theory also defends that in order to be socially responsible, a company must: (1) identify its stakeholders; (2) identify their main demands and (3) establish dialogue mechanisms with them. Thus, the corporate commitment to SD and its stakeholders is not based solely on the core business and performance of the company, but the information on sustainability issues has a relevant place, oriented to provide data on the economic, social and environmental performance of the company. In line with this idea, companies start publishing sustainability reports, which reflect the impact of the company in relation to SD commitments. In accordance, the integrative framework that will be described in this paper has to incorporate the communication perspective as one of the critical issues for the management of sustainability concerns in the business arena.

\subsection{The SD-SRM approach}

In this paper the authors propose that the SD and SRM theories have enough issues in common to justify their integration into a single theoretical framework, called the SD-SRM approach. To justify this proposal, the authors base their reasoning on the previous papers that have somehow explored the separation and/or interconnections of SD and SRM, especially in the hospitality industry (i.e., Jones et al., 2005; Steurer et al., 2005; Konrad et al., 2006; Holcomb et al., 2007; Dodds and Kuehnel, 2010). For example, Dodds and Kuehnel 
(2010) have theoretically defended that SD and SRM are related concepts. They consider that sustainability relates to a company's obligation to be accountable to all of its stakeholders in all its operations and activities with the aim of achieving SD not only in the economic dimension but also in the social and environmental dimensions. Similarly, the World Business Council for Sustainable Development refers to sustainability as a commitment to contribute to sustainable economic development, working with employees, their families, the local community, and society at large to improve their quality of life (Kotler and Lee, 2005). At an empirical and descriptive level, and also subscribing these comprehensive definitions of sustainability, Jones et al. (2005) describe the online sustainability reporting of UK retailers through four stakeholder dimensions that also include sustainable development issues (e.g., energy consumption and emissions, raw material usage, water consumption, charitable contributions to local and national organisations, etc) while Holcomb et al. (2007) implement a content analysis of online information to describe the sustainability reporting of international hospitality companies based on five stakeholder dimensions that also encompass sustainable development concerns.

These ideas also align with the proposals of the Total Responsible Management (TRM), as proposed by Waddock et al. (2002). The TRM is a comprehensive framework that includes the process of managing relationships with stakeholders and organisational impacts within society (Musgrave, 2011). TRM is founded upon a process of continual improvement and innovation, rather than striving for perfection. Indeed, the TRM framework places employee engagement and other key stakeholders as the keystone towards the concept of responsible management. The outcome of this interaction develops improvement and learning systems that help organisations generate better economic, social and environmental returns and greater competitive advantage (Musgrave, 2011).

247 Nonetheless, most of the explored approaches limit their academic contributions to the 248 proposition of comprehensive definitions to understand sustainability but they do not go any 249 further to depict how the integration of stakeholders and the triple-bottom line can be 250 implemented in companies. The SD-SRM approach gives one step further and concentrates on 251 describing the interactions between both theoretical approaches. Roughly speaking, this new line of research analyses the question of how far SD can be achieved through SRM and thus shows how SD and SRM relate to each other (Steurer et al., 2005; Konrad et al., 2006). Along this line, scholars consider that SD can be pursued in many different ways, SRM being one of them. In this regard, through SRM companies are confronted with economic, social and environmental stakeholder claims (Steurer et al., 2005). Thus, SD and SRM can be regarded as two complementary and mutually reinforcing concepts, both aiming to integrate the economic, social and environmental issues in management routines (Konrad et al., 2006; Carroll and Buchholtz, 2011; Rodríguez et al., 2013).

The SD-SRM approach has a triple typology of perspectives to understand the link between SD and stakeholders (Steurer et al., 2005). First, there is a normative perspective that focuses on interpreting the normative characteristics of SD and their significance for SRM theory. This dimension of the SD-SRM approach concentrates on the question 'what issues of SD should companies and stakeholders take into account?'. The descriptive perspective focuses on describing how particular issues of SD play a role in the SRM theory (Steurer et al., 2005). This dimension concentrates on the question 'which issues of SD are taken into account by corporations or stakeholders and in what way?' (Konrad et al., 2006). Finally, there is an instrumental perspective of the SD-SRM approach that analyses the connection between the SRM theory and the realization of SD. The question to analyse in this perspective is 'to what extent can SD be achieved through SRM?'. This last perspective has already been analysed by 
Steurer et al. (2005) who evaluate under which conditions SRM can assist companies in their 272 sustainability goals.

273 Thus, in this paper the authors are interested in the normative and descriptive perspectives of 274 the SD-SRM approach because they have traditionally been the most demanded by scholars and practitioners (Sclegelmich and Öberseder, 2010). On the one hand, the normative perspective prescribes what companies should do (Carroll and Buchholtz, 2011). It seeks to develop ethical standards for companies with regard to the question of right or wrong (sustainable or unsustainable development) (Laczniak and Murphy, 2006). On the other hand, the descriptive (or positive) perspective describes what companies actually do. It tries to describe, explain, and understand sustainability in companies (Sclegelmich and Öberseder, 2010). By analysing both perspectives, the purpose of the authors is to compare theory and practice to find areas for improvement in the management of SD and stakeholders in the hospitality industry.

While the descriptive dimension of the SD-SRM approach will be studied in the following sections of the paper, the authors now focus their attention on presenting the normative perspective of the SD-SRM approach. In this regard, this normative perspective implies that the sustainability model developed for the hospitality industry combines the dimensions of the triple-bottom line with the stakeholders of the company. This fact implies that, under the light of the SD-SRM approach, it is not enough that companies design only some social activities in general terms. They will have to design the best social practices that satisfy the interests of employees (e.g., social benefits, volunteering, etc), customers (e.g., physical accessibility, healthy commercial offer, etc), suppliers (e.g., Code of Conduct, responsible purchasing, etc) and so on (Clarkson, 1995; Carroll and Buchholtz, 2011). Similarly, companies will also have to design the best environmental and economic practices according to the specific concerns of each of their stakeholders, which might be similar or very divergent. For example, while the economic responsibilities of companies towards their shareholders are to assure corporate profitability, customers demand commercial accessibility and promotional marketing, the society demands the implication of companies in the sustainable economic progress of local communities and employees expect that their employers divert money to train them and design good career plans (Clarkson, 1995). In terms of the environmental dimension of the triple-bottom line, Starik (1995) defends that any of several stakeholder management processes can readily include the natural environment as one or more stakeholders of companies. The planet has many representatives willing to come to the table on its behalf. Legislators, regulators, shareholders, consumers, lenders, insurers, employees, environmental groups, and industry standard setters all represent the natural environment in the business arena (Stead and Stead, 2000).

For the proposition of a normative framework to study sustainability in companies, it is also necessary to take into consideration the contextual nature of SD and SRM (Williams and Adams, 2013; Pérez et al., 2014). For example, while sustainability reporting has found to be significant for companies in previous studies (Branco and Rodrigues, 2006; Holcomb et al., 2007; Bravo et al., 2012), the extent of disclosure appeared to differ especially across industry sectors (Tsang, 1998; Ratanajongkol et al., 2006) suggesting context is important (Williams and Adams, 2013). As stipulated by the ISO standards (e.g., ISO 14001, 26000 or 20121), the level of detail and complexity of the sustainability management system, the extent of documentation and reporting and the resources devoted to it depend on a number of factors, such as the scope of the system, the size of an organization and the nature of its activities, products and services. This reason justifies why the ISO standards do not establish absolute requirements for economic, social and environmental performance beyond the commitments 

companies subscribe.

Adams et al. (1998) examine the relationship between sustainability reporting practices across Western Europe and the factors of size, industry and country. They find sustainability information (especially environmental and some employee information) is industry dependent and suggest that this may be a consequence of specific social and political factors. This idea is consistent with the legitimacy theory (Patten, 1992; Deegan, 2002) that looks at sustainability management as a legitimacy and reputation tool responding to pressures by stakeholders in diverse contexts (Pérez et al., 2014). Specifically, the industry in which the company is primarily identified is believed to influence the intensity (Hackston and Milne, 1996; Reverte, 2009; Gamerschlag et al., 2011) and orientation of SD and SRM (Newson and Deegan, 2002; Ghazali, 2007; Holder-Webb et al., 2009) because the stakeholder pressures differ significantly from some industries to others (Brammer and Pavelin, 2006). Based on these ideas, Pérez et al. (2014) observe that there are significant differences in the type of sustainability information reported by basic, consumer goods, finance and service industries. Specifically, finance companies report more information oriented to employees, investors and regulators than any other industry in their study. On the contrary, service companies (including hospitality and tourism companies) especially report information oriented to the community (including the environment) and social activists, while other pieces of information (e.g., information oriented to investors, partners and regulators) are less frequent. This previous evidence highlights the importance of developing a framework to analyse sustainability that attends to the contextual nature of SD and SRM and that encloses the study of sustainability themes within the industry that is being scrutinized (Williams and Adams, 2013).

For the study of sustainability in the hospitality industry, in this paper the authors propose to integrate sustainability issues according to four SD dimensions and six SRM dimensions. This is a theoretical proposal based on a literature review of previous papers that have developed indepth studies of the SD and SRM theories (Elkington, 1998; Jones et al., 2005; Bohdanowicz and Zientara, 2008; de Grosbois, 2012). On the one hand, the SD dimensions included in the model refer to economic, social, environmental and cultural issues. The economic, social and environmental dimensions are included in the traditional triple-bottom line (Elkington, 1998). Nonetheless, the tourism industry, especially hospitality companies, is also very sensitive to cultural issues (Bohdanowicz and Zientara, 2008) and thus the authors consider that cultural practices should form a dimension with its own identity. In this regard, many hotels are located in major cities, often located near cultural heritage sites, and attract growing numbers of travellers, thereby imposing an increased footprint on cultural resources (de Grosbois, 2012). Equally important, the phenomenon of social intercourse between tourists and local residents is regarded as a major driving force behind respect and understanding among nations. Thus, tourism may positively help propagate cultural values that lie at the heart of destinations (Bohdanowicz and Zientara, 2008). On the other hand, to define the SRM dimensions in the model the authors follow the ideas of Jones et al. (2005). These scholars classify sustainability issues into four sets of concerns namely those relating to the marketplace, the workplace, the environment and the community. The term marketplace is seen to embrace both the sourcing of goods (suppliers and shareholders) and their sale to customers (Jones et al., 2005). Furthermore, the workplace dimension refers to corporate employees, including regular employees and managers, and it encompasses the management of all types of human resources issues such as the responsibility of companies to contribute to the reduction in unemployment, training and career opportunities or the diversity of the workforce (Branco and Rodrigues, 2006; Williams and Adams, 2013). Based on these ideas, the authors propose to study sustainability issues as they relate to customers, suppliers, employees, shareholders, society and the environment. 
Table 1 serves as an example of several corporate practices to be integrated in the normative perspective of the SD-SRM approach proposed in this paper. Further development of this table will be discussed at the empirical stage of the research.

Table 1. Sustainability practices from the SD-SRM approach

\begin{tabular}{|c|c|c|c|c|c|c|}
\hline & Customers & Suppliers & Employees & Shareholders & Society & Environment \\
\hline Economic & $\begin{array}{l}\text { Commercial } \\
\text { accessibility; } \\
\text { quality; } \\
\text { promotional } \\
\text { marketing } \\
\end{array}$ & Fair trade & $\begin{array}{l}\text { Financial } \\
\text { benefits; career } \\
\text { planning; } \\
\text { labour market }\end{array}$ & $\begin{array}{l}\text { Corporate } \\
\text { profitability; } \\
\text { information } \\
\text { transparency }\end{array}$ & $\begin{array}{l}\text { Local } \\
\text { economic } \\
\text { progress; R\&D } \\
\text { budget }\end{array}$ & - \\
\hline Social & $\begin{array}{l}\text { Social } \\
\text { awareness; } \\
\text { physical } \\
\text { accessibility; } \\
\text { participation; } \\
\text { security }\end{array}$ & $\begin{array}{l}\text { Sustainability } \\
\text { promotion; } \\
\text { ethics an } \\
\text { emerging } \\
\text { markets; } \\
\text { responsible } \\
\text { purchasing }\end{array}$ & $\begin{array}{l}\text { Equal } \\
\text { opportunities; } \\
\text { diversity; social } \\
\text { benefits; } \\
\text { occupational } \\
\text { risk prevention }\end{array}$ & $\begin{array}{l}\text { Sustainability } \\
\text { indexes; SRI }\end{array}$ & $\begin{array}{l}\text { Human rights; } \\
\text { citizenship } \\
\text { and } \\
\text { philanthropy }\end{array}$ & - \\
\hline Environmental & $\begin{array}{l}\text { Environmental } \\
\text { awareness; } \\
\text { information } \\
\text { accessibility }\end{array}$ & $\begin{array}{l}\text { Sustainability } \\
\text { promotion; } \\
\text { environmental } \\
\text { impact }\end{array}$ & $\begin{array}{l}\text { Environmental } \\
\text { awareness; } \\
\text { Volunteering }\end{array}$ & $\begin{array}{l}\text { Environmental } \\
\text { awareness }\end{array}$ & $\begin{array}{l}\text { R\&D budget; } \\
\text { foundations }\end{array}$ & $\begin{array}{l}\text { Landscape } \\
\text { protection; } \\
\text { protection of } \\
\text { Flora and } \\
\text { Fauna; climate } \\
\text { change; } \\
\text { environmental } \\
\text { guidelines }\end{array}$ \\
\hline Cultural & $\begin{array}{l}\text { Cultural } \\
\text { awareness; } \\
\text { information } \\
\text { accessibility; } \\
\text { commercial } \\
\text { offer }\end{array}$ & $\begin{array}{l}\text { Sustainability } \\
\text { promotion }\end{array}$ & $\begin{array}{l}\text { Cultural } \\
\text { awareness }\end{array}$ & $\begin{array}{l}\text { Cultural } \\
\text { awareness }\end{array}$ & $\begin{array}{l}\text { Promotion of } \\
\text { local culture; } \\
\text { heritage } \\
\text { conservation; } \\
\text { arts and } \\
\text { science }\end{array}$ & - \\
\hline
\end{tabular}

Source: Compiled by the authors

\section{METHOD}

Once the theoretical underpinnings of the SD-SRM approach have been defined from a normative perspective, it is also the purpose of the authors to further develop this framework in the context of the hospitality industry in order to apply it to the descriptive study of the sustainability practices of hospitality companies. For that purpose, the authors develop a framework of sustainability themes for the hospitality industry that is based on the SD-SRM approach and they use it to analyse the online sustainability reporting of hospitality companies operating in Spain. The authors consider sustainability reporting as an interesting research context because (1) first, there seems to be still little information that assesses the state of sustainability reporting in the hospitality industry (Jones et al., 2005; Holcomb et al., 2007; de Grosbois, 2012; Font et al., 2012) and (2) second, stakeholders have stated that they would like to have more systematic information regarding corporate social responsible practices (Font et al., 2012). Stakeholders have traditionally stated that it is usually too hard to get the information needed because sustainability reporting is confusing and not homogeneous among companies (Holcomb et al., 2007). Thus, analysing sustainability reporting from the SDSRM approach can help practitioners and scholars to identify flaws and gaps in corporate reporting, while amending these flaws is crucial if companies are to be held to account for their practices (Font et al., 2012). Online reporting is also important because providing detailed information via the Internet can enhance a company's image as well as provide information for conscious stakeholders (Jones et al., 2005; Holcomb et al., 2007). In this regard, stakeholders prefer sustainability practices to be communicated through so-called 'minimal release' 
channels (such as annual reports and websites) over the use of traditional communication channels (such as the media) (Morsing and Schultz, 2006).

The authors chose Spanish hospitality companies to implement the empirical study because this industry contributes $10.7 \%$ to the GDP of the country, generating more than 2.5 million direct jobs annually and representing incomes of approximately 3,800 million euros each year (Martínez et al., 2013). Additionally, Spain is the fourth most visited country in the world (after France, USA and China) and as so the authors consider that Spanish hospitality companies can be an interesting benchmark for practitioners worldwide. Nonetheless, the hospitality industry in Spain is significantly heterogeneous, with the presence of major hotel chains and independently managed hotels or the identification of various types of accommodations ranging from the traditional 'sun and beach' hotels to newer concepts such as the 'gastronomic' or 'ecologic' tourism, among others. Thus, the generic study of the hospitality industry is not sufficient to generate adequate knowledge about sustainability in Spain. By contrast, targeted studies are needed to understand, in all its complexity, the process of implementation of sustainability practices in hospitality companies.

The authors implemented a content analysis of the websites of hospitality companies (Holcomb et al., 2007; Bohdanowicz and Zientara, 2008; Gröschl, 2011; Font et al., 2012). Specifically, the sample included both hotel chains and independent hotels, selected through a probabilistic and stratified sampling technique (with proportional, random and systematic allocation). The authors created a database of 2,862 hospitality companies with available and active websites based on the information provided by Hostelmarket (monthly journal of hospitality information in Spain). After the sampling procedure, a total of 170 websites were analysed. 41 of the websites reported sustainability information of hotel chains while 129 websites were managed by independent hotels. The statistical error, derived from the probabilistic technique chose to select the hospitality companies for the study, is $7.29 \%$ for a $95 \%$ confidence level ${ }^{1}$. According to previous literature, this percentage is acceptable for this type of sampling method (Hair et al., 2010). Table 2 summarises the profile of the research.

\section{Table 2. Research profile}

\begin{tabular}{ll}
\hline \hline Universe & 2,862 hospitality companies with available website \\
\hline Place/Reach & Spain \\
\hline Dates of field work & January 2012 - March 2012 \\
\hline Sample & $\begin{array}{l}170 \text { hospitality companies } \\
\text { (41 hotel chains and 129 independent hotels) }\end{array}$ \\
\hline Sampling procedure & $\begin{array}{l}\text { Stratified random sampling with proportional allocation } \\
\text { (systematic and random choice) }\end{array}$ \\
\hline Sampling error & $7.29 \%$ for a 95\% confidence level $(\mathrm{p}=\mathrm{q}=0.5)$ \\
\hline
\end{tabular}

To perform the content analysis the authors followed the procedure suggested by Bravo et al. (2012) and Pérez et al. (2014). The authors contacted and trained two independent judges to explore the different types of information disclosed in the websites of the hospitality companies, including annual financial reports, annual management reports, corporate responsibility reports and all the information directly displayed in the websites' internal links (Bravo et al., 2012). This process allowed the authors to address a limitation of previous studies that focused exclusively on the analysis of corporate responsibility reports without

\footnotetext{
$1 n=\frac{Z^{2} * N * P *(1-P)}{(N-1) * e^{2}+Z^{2} * P *(1-P)}$

where

$\mathrm{Z}=95 \%$ confidence level; $\mathrm{N}=$ universe size; $\mathrm{P}=0.5$ probability; $\mathrm{e}=$ sampling error; and $\mathrm{n}=$ sample size
} 
considering additional materials or links containing sustainability information (Bravo et al., 2012).

433 The independent judges were research fellows hired ad-hoc for the study. According to Bakeman and Gottman (1986) and Bravo et al. (2012), a training and supervision system for these judges was established. For this purpose, and after the authors had explained the purposes of the research to the judges, an initial examination of some of the corporate websites was performed by the judges and the authors independently. Afterwards, a meeting was scheduled in order to discuss the most relevant incidents and obtain consensus in the analysis criteria. Subsequently, regular meetings to discuss new incidents and refine the criteria were also arranged. Specifically, each website was analysed by the two judges independently and the inter-judge agreement coefficients in the categories analysed were calculated. The purpose of this estimation was to get a sufficient coefficient of concordance to ensure that the empirical study was rigorous. The coefficients of concordance in the categories analysed were in all cases higher than 90\%, acceptable for this type of method (Neüendorf, 2002) and similar to previous literature (Gram, 2007). In addition, the time horizon of the analysis covered three months (January 2012 to March 2012) so that the variability of the information contained in the web pages as a result of the dynamism of communication in this channel was properly collected (Bravo et al., 2012).

The first step in the content analysis consisted of the definition of a classification system for created by the authors, although it would be subsequently modified, accommodating it, if required, to the information analysed by the independent judges (Bravo et al., 2012). To warrantee the procedure's validity, previous classifications about the dimensions of SD and SRM were considered as starting points (Bravo et al., 2012). The authors began by defining a theoretical classification of fifty-nine sustainability issues, which was based on the proposals of previous scholars who had analysed the online sustainability reporting of companies in diverse industries (Clarkson, 1995; Ayuso and Fullana, 2002; Perrini et al., 2006; Merwe and Wöcke, 2007; Holcomb et al., 2007; Bravo et al., 2012; Williams and Adams, 2013; Pérez et al., 2014). The categories of sustainability issues were classified according to the four SD dimensions and the six SRM dimensions previously presented in the paper. Thus, the authors defined an economic, social, environmental and cultural dimension for each of the six stakeholder dimensions theoretically identified in this paper (customers, suppliers, employees, shareholders, society and environment). In the customer domain, the economic categories of information referred to commercial accessibility, product and service quality and promotional marketing (Perrini et al., 2006; Bravo et al., 2012; Pérez et al., 2014). The social categories referred to social awareness and promotion among customers, physical accessibility, participation in social issues, security, ethics, honesty and transparency and the commercial offer of healthy products for children or the elderly, among others (Clarkson, 1995; Perrini et al., 2006; Merwe and Wöcke, 2007; Bravo et al., 2012; Pérez et al., 2014). The environmental categories included environmental awareness and accessibility to environmental information (Merwe and Wöcke, 2007). Finally, the cultural categories also included cultural awareness and information accessibility (Merwe and Wöcke, 2007). As far as the suppliers dimension was concerned, the authors defined one economic category referring to the promotion of fair trade conditions (Pérez et al., 2014). The social dimension included five categories, named sustainability promotion, ethics and emerging markets, codes of conduct, responsible purchasing and business cooperation (Bravo et al., 2012; Pérez et al., 2014). The environmental dimension included one category that referred to the sustainability promotion (Pérez et al., 2014). No cultural categories were proposed at this stage because previous scholars had not considered this perspective in their studies. In the employee domain, economic categories included financial benefits, career planning and activities oriented to the 
labour market (Clarkson, 1995; Ayuso and Fullana, 2002; Merwe and Wöcke, 2007; Holcomb et al., 2007; Bravo et al., 2012; Pérez et al., 2014). The social categories were related to equal opportunities, diversity, social benefits, occupational risk prevention, training, internal communication, labour integration and internal codes of conduct (Clarkson, 1995; Exceltur, 2003; Perrini et al., 2006; Holcomb et al., 2007; Bravo et al., 2012; Pérez et al., 2014). The environmental categories included environmental awareness and volunteering (Holcomb et al., 2007; Pérez et al., 2014). Finally, no cultural categories were proposed in the employee domain either, mostly due to the lack of previous literature to derive specific items. As far as shareholders were concerned, only two SD dimensions were developed at this stage. Shareholder economic categories related to the provision of information concerning corporate profitability and transparency (Clarkson, 1995; Holcomb et al., 2007; Pérez et al., 2014). Social categories included sustainability indexes and sustainable responsible investments (Exceltur, 2003). The society dimension included three economic categories (i.e., local economic progress, R\&D budget and foundation) (Exceltur, 2003; Holcomb et al., 2007; Bravo et al., 2012; Pérez et al., 2014), three social categories (i.e., human rights, citizenship and philanthropy and foundation) (Clarkson, 1995; Exceltur, 2003; Pérez et al., 2014), three environmental categories (i.e., citizenship and philanthropy, R\&D budget and foundation) (Exceltur, 2003; Bravo et al., 2012; Pérez et al., 2014) and ten cultural categories (i.e., promotion of local culture, heritage conservation, contests, concerts, exhibitions and conferences, R\&D budget, publication services, sports, own cultural resources and foundation) (Clarkson, 1995; Ayuso and Fullana, 2002; Exceltur, 2003; Merwe and Wöcke, 2007; Bravo et al., 2012; Pérez et al., 2014). Finally, the stakeholder named as environment had three categories of environmental information associated with it. These categories referred to the protection of flora and fauna, climate change and environmental guidelines in the organization (Clarkson, 1995; Merwe and Wöcke, 2007; Bravo et al., 2012).

Within each category the authors also identified different codes/items in order to not lose useful information (Bravo et al., 2012; Pérez et al., 2014). For example, the category of product and service quality (economic dimension oriented to customers) contained five codes named "quality policy", "UNE-EN-ISO 9001:2008 certification", "Q certification", "Tripadvisor certification" and "other certifications". The category referring to the participation of customers in social issues (social dimension oriented to customers) included three codes named "satisfaction surveys", "suggestion mailbox" and "participation of customers in socially responsible activities". Nevertheless, during the recording process new categories and codes were created and others had to be modified in order to accommodate new information or to achieve a more accurate classification (Florek et al., 2006; Rowley, 2009). The emergence and modification of these categories and codes required that the judges reviewed all the websites again so the same categorization schema was employed for all the websites and to obtain consistent and comparable information (Bravo et al., 2012). Sixty-seven categories of sustainability information were finally analysed. The seven new categories of information were: (1) the commercial offer of cultural products for customers; (2) the measurement of the environmental impact of the suppliers businesses; (3) the promotion of cultural sustainability among suppliers; (4) the generation of environmental and (5) cultural awareness among shareholders; (6) the patronage of cultural activities for society and (7) the reporting of information concerning the landscape protection promoted by the company. These seven categories were mostly related to the cultural and environmental dimensions of the SD theory that were the least developed dimensions in previous literature.

527 Finally, one hundred and twenty-three codes were used and classified in the sixty-seven 528 sustainability categories defined for the study. Information was distributed according to the 529 following proportions: 34 codes referred to the customer dimension (7 were economic codes; 53019 were social; 3 were environmental and 5 were cultural); 12 codes referred to the suppliers 
dimension ( 1 was a social code; 8 were social; 2 were environmental and 1 was cultural); 21 codes were included in the employees dimension (4 were economic codes; 15 were social codes; 1 was environmental and 1 was cultural); 10 codes referred to the shareholders dimension ( 6 were economic codes; 2 were social, 1 was environmental and 1 was cultural); 31 codes were included in the society dimension ( 5 were economic codes; 5 were social; 4 were environmental and 17 were cultural). Finally, 15 codes were included in the environmental dimension (all the codes referred to the environmental dimension of the SD theory). The appendix at the end of this paper provides further information about the classification system.

During this process, sustainability information was measured similarly to the KLD (Kinder, Lydenberg and Domini) database, which comprises numerical assessments on the sustainability issue areas of: community, corporate governance, diversity of workforce, employee relations, environment, human rights and product issues (Pérez et al., 2014). In this regard, each hospitality company was given a value of either 0 or 1 in each sustainability code depending on whether the company communicated on it (1) or not (0). The valuation of the codes responded to the sentence "This company informs about significant initiatives implemented (or results achieved) in this sustainability domain" (Pérez et al., 2014). The final score of a company in a sustainability category was the weighted average of the evaluations it got in each of the codes forming the category. Finally, it is necessary to specify that, for the purpose of this study, the authors concentrate on the percentage of hospitality companies that report on each of the categories and dimensions of the SD-SRM approach.

\section{FINDINGS}

\subsection{Communication tools for online sustainability reporting}

Although the research goals of this study do not include an assessment of the communication tools used by hospitality companies on the Internet, the authors believe that a brief description of the online sources where sustainability information was found in this research can be useful to understand better how sustainability is being reported in this industry. Thus, before analysing the sustainability reporting practices of hospitality companies from the SDSRM approach, the authors describe Table 3, which shows the communication tools that are being used by hospitality companies to disclosure sustainability information on the Internet.

Table 3. Communication tools for sustainability

\begin{tabular}{lccc}
\hline \hline Source of information & $\begin{array}{c}\text { Total \% of } \\
\text { companies }\end{array}$ & $\begin{array}{c}\text { \% of hotel } \\
\text { chains }\end{array}$ & $\begin{array}{c}\text { \% of independent } \\
\text { hotels }\end{array}$ \\
\hline \hline Sustainability website & 10 & 34 & 2 \\
\hline Sustainability report & 5 & 20 & 1 \\
\hline Media/press website & 19 & 41 & 12 \\
\hline Specific websites for: & & & \\
1. Shareholders and investors & 4 & 15 & 1 \\
2. Employees and the labour market & 21 & 59 & 9 \\
3. Suppliers & 1 & 2 & - \\
4. Intermediaries & 18 & 51 & 8 \\
\hline Online redirection to other institutions & 24 & 29 & 22 \\
\hline Specific media of the hotel companies & 18 & 27 & 16 \\
\hline \hline
\end{tabular}


563 According to the findings, it appears that few companies are using specific communication 564 channels to disclose sustainability information. This fact is particularly evident in the small 565 hotel companies that make up the network of independent hotels in the sample of this study. 566 Specifically, only $10 \%$ of hotel companies operating in Spain have a complete section dedicated 567 to sustainability in their websites, a percentage that rises to $34 \%$ among hotel chains but is 568 restricted to only $2 \%$ among independent hotels. Furthermore, these percentages are 569 drastically reduced when the publication of sustainability reports is analysed, with only $20 \%$ of 570 hotel chains and $1 \%$ of independent hotels regularly publishing such documents. Note also 571 that this is a relatively recent practice in the hospitality industry, since the first reports of these 572 companies date from the late of 2000 (mostly 2007 and 2008).

573 On the contrary, sustainability reporting practices are less structured, even random, as this 574 information is found in various sections of the websites such as the media/press website (41\% 575 of hotel chains and $12 \%$ of independent hotels use this tool), cultural/sports agendas -specific 576 media- ( $27 \%$ and $16 \%$ of companies, respectively) or the bidirectional communication with 577 various stakeholders through specific sections of the corporate website. In the latter area, 578 special attention is devoted to employees and intermediaries (i.e., travel agencies, tour 579 operators and hotel owners), with custom websites implemented by $21 \%$ and $18 \%$ of the 580 hospitality companies in the study respectively. 59\% of the hotel chains include a specific 581 section for employees and $51 \%$ for intermediaries. For independent hotels, these percentages 582 are $9 \%$ and $8 \%$ respectively. The authors also observe that some companies choose to include 583 links redirecting surfers to other websites related to sustainability organizations as another 584 way to express their commitment to sustainable development. Specifically, 29\% of hotel chains 585 and $22 \%$ of independent hotels include links to other websites such as municipalities, non586 profit organizations or companies organizing cultural events, among others. These findings 587 contrast sharply with the volume of companies that make online booking engines available to 588 their customers and intermediaries ( $81 \%$ of all the companies surveyed). Specifically, $98 \%$ of 589 the hotel chains and $76 \%$ of the independent hotels in the sample use this tool on their 590 websites. This places a strong commercial character to this communication channel beyond 591 the traditional role of corporate image generation that has been attributed to corporate 592 websites. In the following section, these findings will also assist the authors in explaining some sustainability reporting practices of hospitality companies.

\subsection{Sustainability reporting from the SD-SRM approach}

It is also observed that there are significant differences between hotel chains and independent hotels concerning the amount of information disclosed in each of the SD and SRM dimensions analysed in this paper. On the one hand, Table 4 shows the percentage of companies reporting on the SD dimensions proposed in the study. It is observed that there are substantial differences between the volumes of information provided by the hotels in each of these dimensions. The authors perform a comparison of means with the statistical software SPSS v.19, which confirms that the observed differences are significant enough to conclude that some SD dimensions are more frequently reported by hospitality companies than others. Specifically, the content analysis of the websites shows that companies especially provide social information ( $91.8 \%$ of all the companies in the sample), followed by environmental (76.5\%), cultural (74.7\%) and economic information (38.2\%). All the differences are statistically significant, except for that found between the environmental and cultural dimensions, which companies communicate very similarly. The most relevant conclusion derived from this analysis refers to the integration of the cultural dimension to the sustainability concept in the hospitality industry. In this case, although the academic theory considers that cultural aspects do not in themselves constitute a dimension of SD, the empirical analysis in the hospitality 
industry shows that this is a fourth fundamental pillar of the concept in this industry. This facet 613 has sufficient authority to be considered a dimension in itself, as evidenced by the significant 614 differences in the volume of communication provided by companies. This dimension is even 615 more significant in the sustainability reporting of the hospitality industry that the economic 616 component, an aspect that companies report on fewer cases. As a justification for this result, the authors consider the significance acquired by the cultural attractiveness of territories in the commercial activity of hospitality companies. In this regard, the appeal of tourism destinations is a source of competitive advantage for hospitality companies. Thus, the reporting and promotion of cultural, sporting and leisure activities of the destinations is useful for hospitality companies because it also helps them to attract tourists and expand their business opportunities.

Table 4. Comparison of means of the sustainability reporting of SD information

\begin{tabular}{|c|c|c|c|c|c|}
\hline \multirow{2}{*}{ SD dimensions } & \multirow{2}{*}{ Total \% of companies } & \multicolumn{3}{|c|}{ Comparison of means } & \multirow{2}{*}{ p-value } \\
\hline & & SD dimensions & Mean & SD & \\
\hline \multirow{3}{*}{ Economic } & \multirow{3}{*}{38.2} & Social & 0.54 & 0.54 & 0.00 \\
\hline & & Environmental & 0.38 & 0.54 & 0.00 \\
\hline & & Cultural & 0.37 & 0.57 & 0.00 \\
\hline \multirow{2}{*}{ Social } & \multirow{2}{*}{91.8} & Environmental & 0.15 & 0.44 & 0.00 \\
\hline & & Cultural & 0.17 & 0.46 & 0.00 \\
\hline Environmental & 76.5 & Cultural & 0.18 & 0.52 & $0.66^{*}$ \\
\hline Cultural & 74.7 & - & - & - & - \\
\hline
\end{tabular}

624

On the other hand, Table 5 shows the percentage of companies communicating various aspects related to their social responsibility towards their stakeholders. The findings demonstrate that there exists a hierarchy of interests in the sustainability reporting of hospitality companies, by which the greatest volume of information is aimed at customers (94.7\% of all the companies in the sample). A significantly lower percentage of companies also include information oriented to the society $(36.5 \%)$, employees $(26.5 \%)$, the environment (22.9\%), suppliers $(9.4 \%)$ and shareholders (6.5\%). The comparative analysis indicates that there are no significant differences between environmental reporting and the information provided to employees, or between the information focused on suppliers and shareholders. In all other cases the differences are statistically significant. These data therefore confirms the commercial nature bestowed on the websites of hospitality companies, which use this tool as an essential channel for communicating with current and potential customers.

\begin{tabular}{|c|c|c|c|c|c|}
\hline \multirow{2}{*}{ Stakeholders } & \multirow{2}{*}{ Total \% of companies } & \multicolumn{3}{|c|}{ Comparison of means } & \multirow{2}{*}{ p-value } \\
\hline & & Stakeholders & Mean & SD & \\
\hline \multirow{5}{*}{ Customers } & \multirow{5}{*}{94.7} & Suppliers & 0.85 & 0.36 & 0.00 \\
\hline & & Employees & 0.68 & 0.47 & 0.00 \\
\hline & & Shareholders & 0.88 & 0.32 & 0.00 \\
\hline & & Society & 0.58 & 0.51 & 0.00 \\
\hline & & Environment & 0.72 & 0.46 & 0.00 \\
\hline \multirow{4}{*}{ Suppliers } & \multirow{4}{*}{9.4} & Employees & 0.17 & 0.38 & 0.00 \\
\hline & & Shareholders & 0.03 & 0.20 & $0.06 *$ \\
\hline & & Society & 0.27 & 0.47 & 0.00 \\
\hline & & Environment & 0.14 & 0.34 & 0.00 \\
\hline \multirow{3}{*}{ Employees } & \multirow{3}{*}{26.5} & Shareholders & 0.20 & 0.42 & 0.00 \\
\hline & & Society & 0.10 & 0.51 & 0.01 \\
\hline & & Environment & 0.04 & 0.45 & $0.31^{*}$ \\
\hline \multirow{2}{*}{ Shareholders } & \multirow{2}{*}{6.5} & Society & 0.30 & 0.47 & 0.00 \\
\hline & & Environment & 0.17 & 0.37 & 0.00 \\
\hline
\end{tabular}




\begin{tabular}{lccccc}
\hline \hline Society & 36.5 & Environment & 0.14 & 0.51 & 0.00 \\
\hline Environment & 22.9 & - & - & - & - \\
\hline \hline
\end{tabular}

637

The results presented can also be disaggregated by categories of information, combining each of the SD dimensions with the SRM dimensions proposed by the SD-SRM approach (Figures 1 and 2). In this sense, it should be first noted that the SD-SRM structure theoretically proposed in this paper is almost fully representative of the communication made by the major hotel chains and independent hotels operating in Spain. Nonetheless, some gaps in sustainability reporting are also observed in both samples. For example, neither hotel chains nor independently managed hotels provide economic information to suppliers. They do not provide environmental and cultural information specifically oriented to employees and shareholders either. Furthermore, in Figure 2 it can be seen that the social dimension of the relationship with shareholders and the cultural dimension of the relationship with suppliers are not part of the sustainability reporting carried out by independent hotels. These results do not come but to confirm and justify the low rates of information that independent hotels provide to these stakeholders in their websites. Along with these results, it is also noticeable that a number of specific categories of information are not part of the reporting scheme of independent hotels, a fact that significantly differentiates these companies of hotel chains operating in Spain. Specifically, these categories refer to (1) information transparency in the field of shareholders, (2) equal opportunities, diversity, risk prevention and labour integration in the area of employees, (3) promotion of social responsibility, business cooperation and estimation of the environmental impact in the field of suppliers, (4) social awareness of customers and (5) the protection of human rights, within society.

Regarding the amount of companies that report information in each category, the results highlight the relevance of the social dimension oriented to customers, both among hotel chains $(100 \%$ of companies report on this subject) and independent hotels $(89.1 \%)$. The environmental (90.2\% and $67.4 \%$, respectively) and cultural dimensions $(80.5 \%$ and $68.2 \%$, respectively) are also noteworthy. The main differences between the two types of companies in this field are in the treatment given to employees: while they are the second group of interest in the sustainability reporting of hotel chains, they are overwhelmed by the level of information that independent hotels provide at the society and environmental levels.

Concerning more specific subcategories, among hotel chains the provision of commercial information about social products (health, children and senior care, sports) receives special attention $(100 \%)$ as well as the safety of customers $(97.6 \%)$, their participation in social activities (87.8\%) and the accessibility to environmental and cultural information of the tourism destinations ( $82.9 \%$ and $78 \%$, respectively). Outside the customers' dimension, the information provided to society, such as corporate philanthropy (39\%), the promotion of the local culture of destinations (34.1\%), R\&D budget (34.1\%) or environmental philanthropy (31.7\%), is also relevant.

Independent hotels also give special importance to the provision of social goods (65.1\%) and the accessibility to environmental (67.4\%) and cultural information (64.3\%) of the tourism destination. Customer participation (58.9\%) and customer safety $(58.1 \%)$ are also relevant. Out of this area, the authors particularly highlight the contribution of hotels to heritage conservation (15.5\%), because a good number of hotels occupy historic buildings or their facilities are nestled in municipalities with high heritage recognized by UNESCO or other institutions of recognized national and international prestige. As a negative point of these companies, the authors highlight the low weight acquired by many of the SD categories that form the contribution of the hospitality industry to the sustainability concept. 
Figure 1. Sustainability reporting in hotel chains

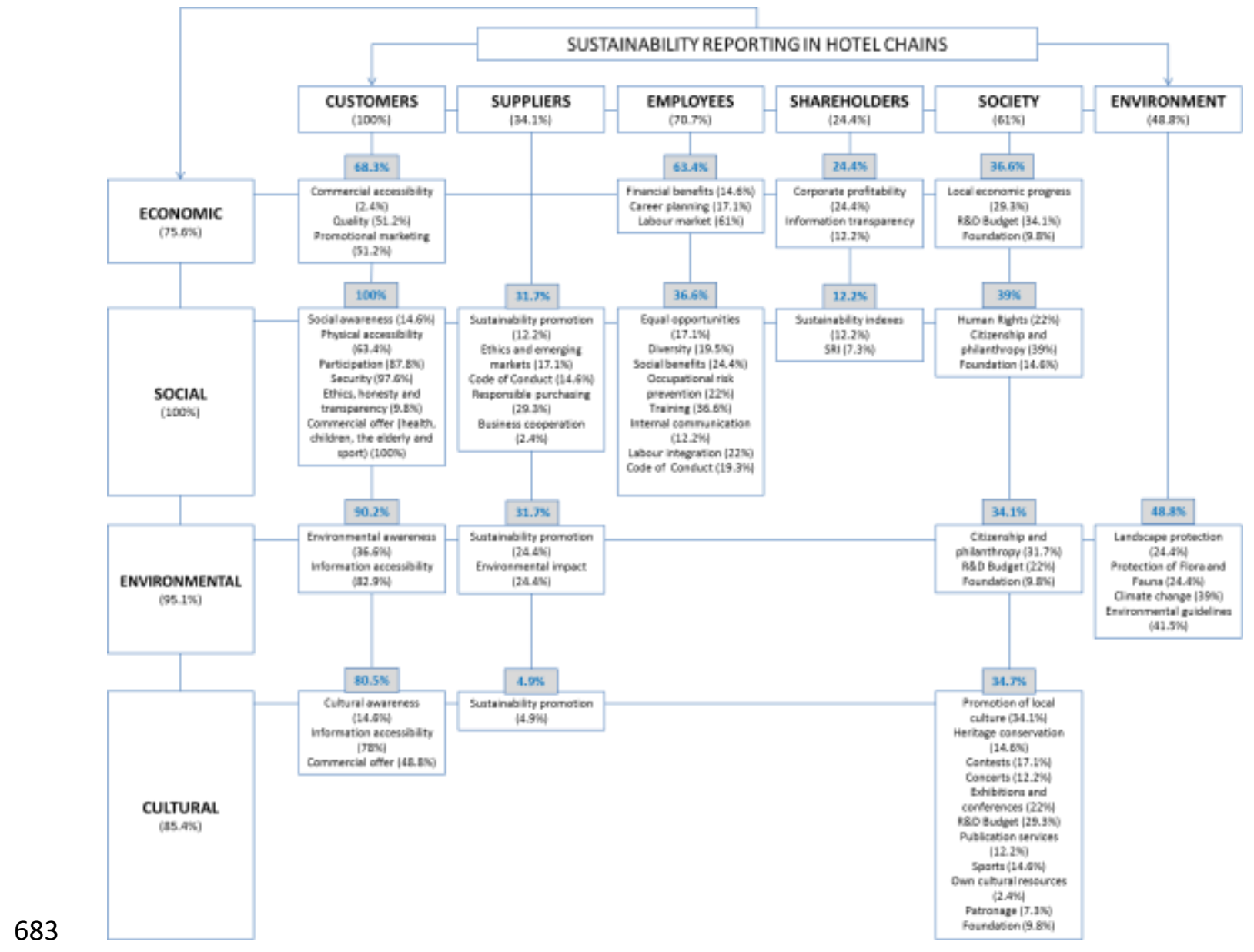

684 Note: The numbers in this figure represent the percentage of companies that report each of 685 the information categories and dimensions 
Figure 2. Sustainability reporting in independent hotels

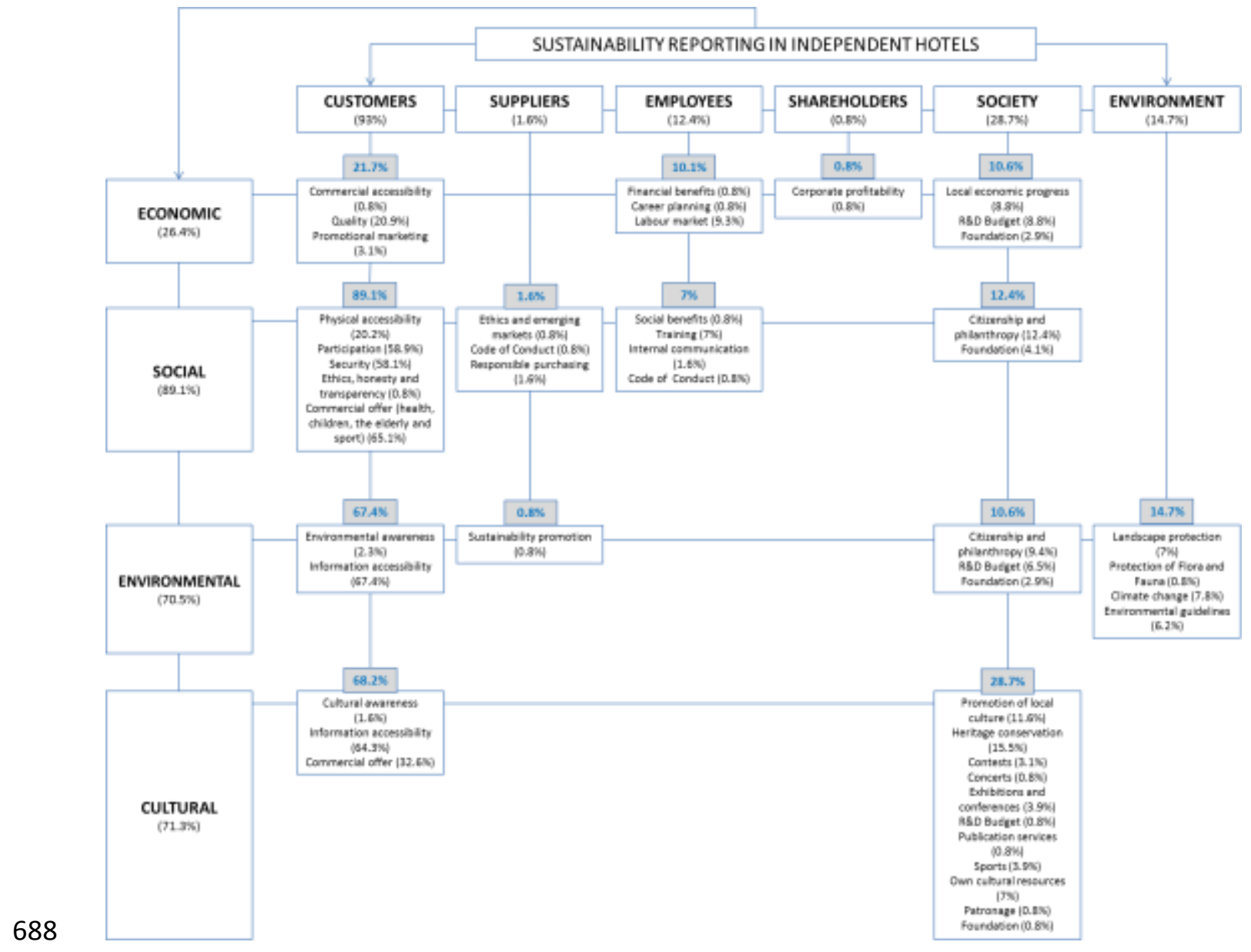

689 Note: The numbers in this figure represent the percentage of companies that report each of 690 the information categories and dimensions 
692 Through this research, the authors have sought to identify a suitable theoretical framework for 693 the implementation and study of sustainability in the hospitality industry. In this regard, 694 sustainability is a concept that is gaining in complexity as it sits in the academic sphere and companies begin to accept its basic principles. Thus, there is a necessity to develop more comprehensive frameworks that assist companies and scholars in identifying better ways to manage and communicate sustainability practices. At the same time, the authors have empirically applied their theoretical framework to the description and evaluation of the current situation of sustainability reporting via the Internet. The findings allow the authors to draw detailed conclusions for a better use of sustainability reporting by the hospitality industry. The main conclusions from this study are presented next.

First, the authors have proposed their theoretical framework, the SD-SRM approach, for the study of sustainability based on the analysis of relevant corporate practices implemented in the field of four dimensions of sustainable development -economic, social, environmental and cultural- and six stakeholders -customers, suppliers, employees, shareholders, society and the environment-. Further, the conceptual framework is applied to the study of the reporting practices of two samples of hospitality companies with very different sustainability approaches. In doing so, the authors observe that the conceptual framework is adequate for describing the sustainability reporting conducted by big hotel chains as well as small to medium size independently managed hotels.

711 This new approach to the study of sustainability also allows the authors to complete the the academic and business world (Jones et al., 2005; Steurer et al., 2005; Konrad et al., 2006; Holcomb et al., 2007; Dodds and Kuehnel, 2010) Thus, it provides a more detailed picture of the level of development and implementation of sustainability in the hospitality industry. The information extracted from this research is therefore more detailed and it has more explanatory power than previous studies. In this regard, the authors would like to especially emphasize the incorporation of a fourth sustainability dimension to the classic perspective of the triple-bottom line. Here, alongside the traditional economic, social and environmental dimensions, the authors determine that sustainability in the hospitality industry is also composed of a cultural dimension. This aspect is of vital importance in this context, as the cultural heritage of tourism destinations represents one of their main attractions and it is a conditioning factor that companies are using very wisely to shape their sustainability policies and attract new customers.

The detailed study of the types of sustainability information provided by companies also shows some relevant results worth noting in this section. First, it emphasizes the use of corporate websites primarily as a business tool, both in the case of major hotel chains as in the case of independently managed hotels. This fact is evidenced primarily in the high volume of customer communication that appears on corporate websites. In this regard, it has been found that customers are the stakeholders that receive more information through electronic means, sometimes with a very unequal distribution with respect to other stakeholders such as suppliers or shareholders, who receive significantly less amounts of sustainability information. Over $90 \%$ of the companies provide some type of information to customers, a percentage that rises up to $100 \%$ in the case of hotel chains. In addition, it has been found that $81 \%$ of the hotels in the sample show online booking engines as a means of selling their services through their own websites. In line with this commercial character identified in corporate websites, the authors have also found that a large volume of companies report on sustainability issues that are directly linked to the core business of the company. Specifically, companies provide a high volume of information in terms of the natural heritage ( $71.2 \%$ of hospitality companies in the 
740 sample) and cultural resources (67.6\%) of tourism destinations, which are aspects that directly 741 affect the attractiveness of not only the destinations but also the hotels themselves.

742 With regard to the other stakeholders that relate to sustainability in the hospitality industry, compared to other industries with less impact on the physical environment (e.g., banking or retailing). Along this line, even though the environment has traditionally not been considered an interest group in itself, because of the absence of a personal nature thereof, in the hospitality industry it is a vital focus of attention (Rodríguez et al., 2013). Thus, the traditional classification of sustainability that splits the concept into five groups of key stakeholders customers, employees, society, shareholders and suppliers- must be adapted to identify six relevant groups in the hospitality industry, which also includes the environment. The justification of this idea is found in two facts evidenced in this research: 1) the high volume of available information on environmental practices and 2) the internal formalization of environmental policies in hospitality companies. On the one hand, it has been shown that around $76.5 \%$ of companies report some aspect of sustainability directly related to environmental issues, including the percentage of both large chains and small independent hotels. In addition, $22.9 \%$ of companies report issues specifically grouped in the dimension called "environment", such as practices to combat climate change, the protection of landscapes or the preservation of Flora and Fauna in the areas of corporate influence. The rest of companies also communicate on environmental issues, but with a more immediate impact on the relationship with other stakeholders. For example, monitoring environmental impacts among suppliers or the promotion of customers' and employees' awareness on this subject are included in this second category. As for the formalization of environmental policies within hotels, it is noticeable how a large number of chains and independent hotels are adopting formal structures in their environmental policies. In this sense, even though it is true that still few companies adopt a comprehensive sustainability policy, the number increases if we consider those that at least have some kind of formalized management system or environmental certification ( $15 \%$ of companies in the sample). These results confirm the contextual nature of corporate sustainability that must be recognized in its definition and implementation by accounting for the different nuances in diverse industries and companies (Williams and Adams, 2013). For example, the findings of this study contradict the results observed by Konrad et al. (2006) when analysing sustainability in a multi-industry context. These authors observed that the economic dimension of sustainable development was the most important one in most industries as issues such as financial performance and long-term competitiveness were the most frequently reported by companies. Thus, the implications of sustainability in the hospitality industry are quite different to its implications in other economic contexts.

The findings concerning the role of suppliers in the definition of the relationships established between hospitality companies and their environment also lead to a relevant conclusion of this study. In this case, it is surprising to corroborate the absence of a specific dimension that collects the economic implications of the hotel relationships with these stakeholders. Analysing the practices defined in the industry in relation to these stakeholders, it seems that sustainability in this area focuses more on obligations imposed on suppliers by the hotels than on practices that truly represent mutual benefit for both parties. In this sense, the most frequent dimensions identified in the study talk about the establishment of codes of conduct, procedures for responsible purchasing, the stimulation of the responsibility of suppliers on social, environmental and cultural terms, and the estimation of the environmental impact of the whole supply chain. This result is in line with the findings of Dodds and Kuehnel (2010). The authors of this paper consider that the lack of initiatives that promote the mutual benefit of hospitality companies and their suppliers can be detrimental for the establishment of 
sustainable relationships among them. When managing sustainability, hospitality companies are imposing high pressures on suppliers to comply with sustainable practices but they are not offering explicit benefits to compensate those efforts. This fact might harm the willingness of suppliers to hospitality companies and undermine sustainable development in the industry.

The findings of the paper have significant implications for hospitality practitioners. First, hospitality companies should try to improve the organization and presentation of their online sustainability reporting as it is now scattered through their websites and, sometimes, relevant information is not clearly presented. Organizing their sustainability reports following the theoretical structure proposed by the SD-SRM approach or activating specific sections of corporate websites to each of the six stakeholders defined in this paper could assist companies in this task. Secondly, all hospitality companies should value the cultural information of tourism destinations because this is a key component for sustainable development in the hospitality industry. Thirdly, companies would benefit from rethinking their communicative relationship with some stakeholders such as suppliers, which are not being informed of key sustainability issues for them (i.e., economic issues).

\section{LIMITATIONS AND FUTURE LINES OF RESEARCH}

The study is not without limitations. First, the research has had an exploratory purpose and thus the authors have not implemented statistical tests to prove the reliability and validity of the theoretical framework presented in this paper. The aim of the research has been to present the SD-SRM approach from a normative perspective and to apply it with descriptive purposes in the hospitality industry. Once the approach has been described, future researchers should search for complete and reliable measurement scales that assist scholars and practitioners in better studying and implementing sustainability practices from the SDSRM approach. Along this line, it is also noticeable that the authors have evaluated the sustainability reporting of hospitality companies by only considering the quantity of sustainability information provided by hotels on the Internet. Nonetheless, the quality of the information provided by companies is also relevant in the study of sustainability reporting (Piechocki, 2004). Future lines of research should provide more sophisticated ways of evaluating the sustainability reporting by also taking into account the quality of the reporting from a SD-SRM approach. Thirdly, the authors have also encountered problems of comparability in the sustainability information provided by the hospitality companies in the study. This problem has also been reported by previous scholars such as Bonilla and Avilés (2008). In this regard, although most of the hotels report on the same economic, social, environmental, cultural and stakeholder issues, the information is not wholly comparable because there is no available information about how data are measured by companies. Even when hotels use the same indicators, they do not always use the same reporting units, as in the case of reporting environmental waste sometimes by weight and sometimes by volume. Future research should try to control for this specificity in sustainability reporting. Finally, the conceptual framework presented in this paper has been applied to a limited research context (i.e. hospitality companies in Spain). Thus, its suitability has not been tested across regions or nations. New studies should test the conceptual model in different research contexts in order to corroborate and extend the conclusions extracted from this paper. 
837 Adams, C.A.; Hill, W.Y. and Roberts, C.B. (1998): "Corporate social reporting practices in 838 western Europe: legitimating corporate behaviour?". British Accounting Review, 14(3), 31-39.

839 Agarwal, S. (2002): "Restructuring seaside tourism: The resort lifecycle". Annals of Tourism 840 Reearch, 29(1), 25-55.

841 Ayuso, S. and Fullana, P. (2002): Sustainable tourism. Rubes, Barcelona.

842 Bakeman, R. and Gottman, J.M. (1986): Observing interaction: An introduction to sequential 843 analysis. Cambridge University Press, Cambridge.

844 Bigné, E.; Font, X. and Andreu, L. (2000): Tourist destinations marketing. Esic, Madrid.

845 Bohdanowicz, P. and Zientara, P. (2008): "Hotel companies' contribution to improving the 846 quality of life of local communities and the well-being of their employees". Tourism and 847 Hospitality Research, 9(2), 147-158.

848 Bonilla, M.J. and Avilés, C. (2008): "Analysis of environmental statements issued by EMAS849 Certified Spanish hotels". Cornell Hospitality Quarterly, 49(4), 381-394.

850 Brammer, S.J. and Pavelin, S. (2006): "Corporate reputation and social performance: The 851 importance of fit". Journal of Management Studies, 43(3), 435-455.

852 Branco, M.C. and Rodrigues, L.L. (2006): "Communication of corporate social responsibility by 853 Portuguese banks". Corporate Communications: An International Journal, 11(3), 232-248.

854 Bravo, R.; Matute, J. and Pina, J.M. (2012): "Corporate social responsibility as a vehicle to reveal the corporate identity: A study focused on the websites of Spanish financial entities". Journal of Business Ethics, 107(2), 129-146.

Carroll, A.B. and Buchholtz, A.K. (2011): Business and society: Ethics, sustainability, and stakeholder management. Cengage Learning.

Castro, C.J. (2004): "Sustainable development: Mainstream and critical perspectives". Organization \& Environment, 17(2), 195-225.

Clarkson, M.B.E. (1995): “A stakeholder framework for analyzing and evaluating corporate social performance". Academy of Management Review, 20, 92-117.

Dahlsrud, A. (2008): "How corporate social responsibility is defined: An analysis of 37 definitions". Corporate Social Responsibility and Environmental Management, 15, 1-13.

Deegan, C. (2002): "The legitimising effect of social and environmental disclosures: A theoretical foundation". Accounting, Auditing and Accountability Journal, 15(3), 282-311.

de Grosbois, D. (2012): “Corporate social responsibility reporting by the global hotel industry: Commitment, initiatives and performance". International Journal of Hospitality Management, 31, 896-905.

Dodds, R. and Kuehnel, J. (2010): "CSR among Canadian mass tour operators: Good awareness but little action". International Journal of Contemporary Hospitality Management, 22(2), 221244.

Dyllick, T. and Hockerts, K. (2002): "Beyond the business case for corporate sustainability". Business Strategy and the Environment, 11, 130-141.

Elkington, J. (1998): "Partnerships from Cannibals with Forks: The triple-bottom line of $21^{\text {st }}$ century business". Environmental Quality Management, 8(1), 37-51.

European Commission (2001): Green Paper: Promoting a European framework for corporate social responsibility. Commission of the European Communities, Brussels.

Exceltur (2003): Acción social en la empresa turística. Alianza para la Excelencia Turística, Madrid.

Florek, M.; Insch, A. and Gnoth, J. (2006): "Papers city council websites as a means of place brand identity communication". Place Branding, 2(4), 276-296.

Freeman, R.E. (1984): Strategic management: A stakeholder approach. Pittman, Boston, MA. Font, X.; Walmsley, A.; Cogotti, S.; McCombes, L. and Häusler, N. (2012): "Corporate social responsibility: The disclosure-performance gap". Tourism Management, 33, 1544-1553. 
Gamerschlag, R.; Möller, K. and Verbeeten, F. (2011): "Determinants of voluntary CSR disclosure: Empirical evidence from Germany". Review of Managerial Science, 5, 233-262.

Ghazali, N.A.M. (2007): "Ownership structure and corporate social responsibility disclosure: Some Malaysian evidence". Corporate Governance, 7(3), 251-256.

890 Gram, M. (2007): "Children as co-decision makers in the family? The case of family holidays". 891 Young Consumers, 8(1), 19-28.

892 Gröschl, S. (2011): "Diversity management strategies of global hotel groups: A corporate web site based exploration". International Journal of Contemporary Hospitality Management, 23(2), 224-240. Hackston, D. and Milne, M.J. (1996): "Some determinants of social and environmental disclosures in New Zealand companies". Accounting, Auditing and Accountability Journal, 9(1), 77-108.

898 Hair, J.F.; Black, W.C.; Babin, B.J. and Anderson, R.E. (2010). Multivariate data analysis (7th

Henderson, J.C. (2007): "Corporate social responsibility and tourism: Hotel companies in Phuket, Thailand, after the Indian Ocean tsunami". International Journal of Hospitality Management, 26(1), 228-239.

Holcomb, J.L.; Upchurch, R.S. and Okumus, F. (2007): “Corporate social responsibility: What are top hotel companies reporting?". International Journal of Contemporary Hospitality Management, 19(6), 461-476.

Holder-Webb, L.; Cohen, J.R.; Nath, L. and Wood, D. (2009): "The supply of corporate social responsibility disclosures among US firms". Journal of Business Ethics, 84, 497-527.

Hopkins, M. (2003): The planetary bargain - CSR matters. Earthscan, London.

Jones, P.; Comfort, D. and Hillier, D. (2005): "Reporting and reflecting on corporate social responsibility in the hospitality industry: A case study of pub operators in the UK". International Journal of Contemporary Hospitality Management, 18(4), 329-340.

Kakabadse, N.K.; Rozuel, C. and Lee-Davies, L. (2005): "Corporate social responsibility and stakeholder approach: A conceptual review". International Journal of Business Governance and Ethics, 1(4), 277-302.

Konrad, A.; Steurer, R.; Langer, M.E. and Martinuzzi, A. (2006): "Empirical findings on businesssociety relations in Europe”. Journal of Business Ethics, 63, 89-105.

Kotler, P. and Lee, N. (2005): Corporate social responsibility. Doing the most good for your company and your cause. John Wiley \& Sons, Hoboken, NJ.

Laczniak, G.R. and Murphy, P.E. (2006): “Normative perspectives for ethical and socially responsible marketing". Journal of Macromarketing, 26(2), 154-177.

Maignan, I. and Ferrell, O.C. (2004): "Corporate social responsibility and marketing: An integrative framework". Journal of the Academy of Marketing Science, 32(1), 3-19.

Martínez, R.P.; Pérez, A. and Rodríguez del Bosque, I. (2013): “Measuring corporate social responsibility in tourism: Development and validation of an efficient measurement scale in the hospitality industry". Journal of Travel \& Tourism Marketing, 30, 365-385.

Merwe, M.v.d. and Wöcke, A. (2007): "An investigation into responsible tourism practices in the South African hotel industry". South African Journal of Business Management, 38(2), 1-12. Morsing, M. and Schultz, M. (2006): "Corporate social responsibility communication: Stakeholder information, response and involvement strategies". Business Ethics: A European Review, 15(1), 323-338.

Musgrave, J. (2011): “Moving towards responsible events management". Worldwide Hospitality and Tourism Themes, 3(3), 258-274.

Neüendorf, K.A. (2002): The content analysis guidebook. Sage Publications, Thousand Oaks, CA.

Newson, M. and Deegan, C. (2002): "Global expectations and their association with corporate social disclosure practices in Australia, Singapore and South Korea". The International Journal of Accounting, 37, 183-213. 
Panwar, R.; Rinne, T.; Hansen, E. and Juslin, H. (2006): “Corporate responsibility: Balancing 939 economic, environmental and social issues in the forest products industry". Forest Products 940 Journal, 56(2), 4-12.

941 Patten, D.M. (1992): "Intra-industry disclosure in response to the Alaskan oil spill: A note on 942 legitimacy theory". Accounting, Organizations and Society, 17(5), 471-475.

943 Pérez, A.; García de los Salmones, M.M. and López, C. (2014): "Corporate reputation in the 944 Spanish context: An interaction between reporting to stakeholders and industry". Journal of 945 Business Ethics, in press. Available online. DOI: 10.1007/s10551-014-2199-3.

946 Perrini, F.; Pogutz, S. and Tencati, A. (2006): “Corporate social responsibility in Italy: State of 947 the art". Journal of Business Strategies, 23(1), 65-91.

948 Piechocki, R. (2004): "Industry survey: Transparency of annual sustainability reports". 949 Corporate Reputation Review, 7(2), 107-123.

950 Ratanajongkol, S.; Davey, H. and Low, M. (2006): "Corporate social reporting in Thailand". 951 Qualitative Research in Accounting and Management, 3(1), 67-83.

952 Reverte, C. (2009): "Determinants of corporate social responsibility disclosure ratings by 953 Spanish listed firms". Journal of Business Ethics, 88, 351-366.

954 Rodríguez, J.M.; Alonso, M.M. and Celemín, M.S. (2013): “Corporate social responsibility in 955 Spanish hotel industry. A case study". Revista de Responsabilidad Social de la Empresa, 5(1), 15-50.

Rowley, J. (2009): “Online branding strategies of UK fashion retailers". Internet Research, 19(3), 348-369.

Sclegelmich, B.B. and Öberseder, M. (2010): "Half a century of marketing ethics: Shifting perspectives and emerging trends". Journal of Business Ethics, 93, 1-19.

Starik, M. (1995): "Should trees have managerial standing? Toward stakeholder status for nonhuman nature". Journal of Business Ethics, 14, 207-217.

Stead, J.G. and Stead, E. (2000): "Eco-enterprise strategy: Standing for sustainability". Journal of Business Ethics, 24, 313-329.

965 Steurer, R.; Langer, M. E.; Konrad, A. and Martinuzzi, A. (2005): "Corporations, stakeholders 966 and sustainable development: A theoretical exploration of business-society relations". Journal 967 of Business Ethics, 61, 263-281.

968 Tsang, E.W.K. (1998): "A longitudinal study of corporate social reporting in Singapore". 969 Accounting, Auditing and Accountability Journal, 11(5), 624-635.

970 van Marrewijk, M. (2003): “Concepts and definitions of CSR and corporate sustainability: Between agency and communion. Journal of Business Ethics, 44(2), 95-105.

Waddock, S.A.; Bodwell, C. and Graves, S.B. (2002): "Responsibility: The new business imperative". Academy of Management Executive, 16(2), 132-148.

Wheeler, D.; Fabig, H. and Boele, R. (2002): "Paradoxes and dilemmas for stakeholder responsive firms in the extractive sector: Lessons from the case of Shell and the Ogoni". Journal of Business Ethics, 39, 297-318.

Williams, S.J. and Adams, C.A. (2013): "Moral accounting? Employee disclosures from a stakeholder accountability perspective". Accounting, Auditing and Accountability Journal, 26(3), 449-495.

World Bank (2004): Corporate social responsibility. Available at: http://www.worldbank.org.

\section{APPENDIX}


Table 6. Dimensions and categories of sustainability reporting practices from the SD-SRM approach

\begin{tabular}{|c|c|c|c|}
\hline SRM dimension & SD dimension & $\begin{array}{ll}\text { Category of sustainability information } \\
\end{array}$ & References \\
\hline \multirow{14}{*}{ Customers } & \multirow{3}{*}{ Economic } & 1. Commercial accessibility* & \multirow{3}{*}{ Perrini et al. (2006); Bravo et al. (2012); Pérez et al. (2014) } \\
\hline & & 2. Quality* & \\
\hline & & 3. Promotional marketing* & \\
\hline & \multirow{6}{*}{ Social } & 4. Social awareness* & \multirow{6}{*}{$\begin{array}{l}\text { Clarkson (1995); Perrini et al. (2006); Merwe and Wöcke } \\
\text { (2007); Bravo et al. (2012); Pérez et al. (2014) }\end{array}$} \\
\hline & & 5. Physical accessibility* & \\
\hline & & 6. Participation* & \\
\hline & & 7. Security* & \\
\hline & & 8. Ethics, honesty and transparency* & \\
\hline & & 9. Commercial offer (health, children, the elderly and sports)* & \\
\hline & \multirow{2}{*}{ Environmental } & 10. Environmental awareness* & \multirow{2}{*}{ Merwe and Wöcke (2007); Pérez et al. (2014) } \\
\hline & & 11. Information accessibility* & \\
\hline & \multirow{3}{*}{ Cultural } & 12. Cultural awareness* & \multirow{3}{*}{ Merwe and Wöcke (2007); Pérez et al. (2014) } \\
\hline & & 13. Information accessibility* & \\
\hline & & 14. Commercial offer & \\
\hline \multirow{9}{*}{ Suppliers } & Economic & 15. Fair trade* & Pérez et al. (2014) \\
\hline & \multirow{5}{*}{ Social } & 16. Sustainability promotion* & \multirow{5}{*}{ Bravo et al. (2012); Pérez et al. (2014) } \\
\hline & & 17. Ethics and emerging markets* & \\
\hline & & 18. Code of Conduct* & \\
\hline & & 19. Responsible purchasing* & \\
\hline & & 20. Business cooperation* & \\
\hline & \multirow{2}{*}{ Environmental } & 21. Sustainability promotion* & \multirow{2}{*}{ Pérez et al. (2014) } \\
\hline & & 22. Environmental impact & \\
\hline & Cultural & 23. Sustainability promotion & New category \\
\hline \multirow{11}{*}{ Employees } & \multirow{3}{*}{ Economic } & 24. Financial benefits* & \multirow{3}{*}{$\begin{array}{l}\text { Clarkson (1995); Ayuso and Fullana (2002); Merwe and } \\
\text { Wöcke (2007); Holcomb et al. (2007); Bravo et al. (2012); } \\
\text { Pérez et al. (2014) }\end{array}$} \\
\hline & & 25. Career planning* & \\
\hline & & 26. Labour market* & \\
\hline & \multirow{8}{*}{ Social } & 27. Equal opportunities* & \multirow{8}{*}{$\begin{array}{l}\text { Clarkson (1995); Exceltur (2003); Perrini et al. (2006); } \\
\text { Holcomb et al. (2007); Bravo et al. (2012); Pérez et al. (2014) }\end{array}$} \\
\hline & & 28. Diversity* & \\
\hline & & 29. Social benefits* & \\
\hline & & 30. Occupational risk prevention* & \\
\hline & & 31. Training* & \\
\hline & & 32. Internal communication* & \\
\hline & & 33. Labour integration* & \\
\hline & & 34. Code of Conduct* & \\
\hline
\end{tabular}




\begin{tabular}{|c|c|c|c|}
\hline & & 35. Environmental awareness* & \\
\hline & Environmental & 36. Volunteering* & Holcomb et al. (2007); Perez et al. (2014) \\
\hline & Cultural & 37. Cultural awareness & New category \\
\hline \multirow{6}{*}{ Shareholders } & \multirow{2}{*}{ Economic } & 38. Corporate profitability* & \multirow{2}{*}{ Clarkson (1995); Holcomb et al. (2007); Pérez et al. (2014) } \\
\hline & & 39. Information transparency* & \\
\hline & \multirow{2}{*}{ Social } & 40. Sustainability indexes* & \multirow{2}{*}{ Exceltur (2003) } \\
\hline & & 41. Sustainable Responsible Investments (SRI)* & \\
\hline & Environmental & 42. Environmental awareness & New category \\
\hline & Cultural & 43. Cultural awareness & New category \\
\hline \multirow{20}{*}{ Society } & \multirow{3}{*}{ Economic } & 44. Local economic progress* & \multirow{3}{*}{$\begin{array}{l}\text { Exceltur (2003); Holcomb et al. (2007); Bravo et al. (2012); } \\
\text { Pérez et al. (2014) }\end{array}$} \\
\hline & & 45. R\&D budget* & \\
\hline & & 46. Foundation* & \\
\hline & \multirow{3}{*}{ Social } & 47. Human Rights* & \multirow{3}{*}{ Clarkson (1995); Exceltur (2003); Pérez et al. (2014) } \\
\hline & & 48. Citizenship and philanthropy* & \\
\hline & & 49. Foundation* & \\
\hline & \multirow{3}{*}{ Environmental } & 50. Citizenship and philanthropy* & \multirow{3}{*}{ Exceltur (2003); Bravo et al. (2012); Pérez et al. (2014) } \\
\hline & & 51. R\&D budget* & \\
\hline & & 52. Foundation* & \\
\hline & \multirow{11}{*}{ Cultural } & 53. Promotion of local culture* & \multirow{11}{*}{$\begin{array}{l}\text { Clarkson (1995); Ayuso and Fullana (2002); Exceltur (2003); } \\
\text { Merwe and Wöcke (2007); Bravo et al. (2012); Pérez et al. } \\
\text { (2014) }\end{array}$} \\
\hline & & 54. Heritage conservation* & \\
\hline & & 55. Contests* & \\
\hline & & 56. Concerts* & \\
\hline & & 57. Exhibitions and conferences* & \\
\hline & & 58. R\&D budget* & \\
\hline & & 59. Publication services* & \\
\hline & & 60. Sports* & \\
\hline & & 61. Own cultural resources* & \\
\hline & & 62. Patronage & \\
\hline & & 63. Foundation* & \\
\hline \multirow{4}{*}{ Environment } & \multirow{4}{*}{ Environmental } & 64. Landscape protection & \multirow{4}{*}{$\begin{array}{l}\text { Clarkson (1995); Merwe and Wöcke (2007); Bravo et al. } \\
\text { (2012) }\end{array}$} \\
\hline & & 65. Protection of Flora and Fauna* & \\
\hline & & 66. Climate change* & \\
\hline & & 67. Environmental guidelines* & \\
\hline
\end{tabular}

Note: categories marked with a * refer to the fifty-nine sustainability issues originally proposed by the authors. The rest of categories are new sustainability issues identified by the independent judges during the content analysis of the corporate websites 